\title{
CRTC2 wt Allele
}

National Cancer Institute

\section{Source}

National Cancer Institute. CRT C2 wt Allele. NCI Thesaurus. Code C95454.

Human CRT C2 wild-type allele is located in the vicinity of $1 \mathrm{q} 21.3$ and is approximately 11

$\mathrm{kb}$ in length. This allele, which encodes CREB-regulated transcription coactivator 2

protein, plays a role in the positive regulation of transcription. 